Winter 2012

\title{
The Myth of Generic Pharmaceutical Competition under the Hatch-Waxman Act
}

\author{
Emily Michiko Morris
}

emm6486@psu.edu

Follow this and additional works at: https://ideas.dickinsonlaw.psu.edu/fac-works

\section{Recommended Citation}

Emily Michiko Morris, The Myth of Generic Pharmaceutical Competition under the Hatch-Waxman Act, 22 Fordham Intell. Prop. Media \& Ent. L.J. 245 (2012).

This Article is brought to you for free and open access by the Faculty Scholarship at Dickinson Law IDEAS. It has been accepted for inclusion in Faculty Scholarly Works by an authorized administrator of Dickinson Law IDEAS. For more information, please contact lja10@psu.edu. 


\title{
The Myth of Generic Pharmaceutical Competition Under the Hatch-Waxman Act
}

\author{
Emily Michiko Morris*

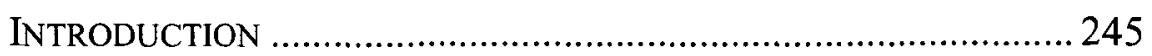 \\ I. The PharmaceUtical IndUStRy: A PRIMER .............. 251 \\ II. THE HATCH-WAXMAN ACT ......................................... 260 \\ III. Pharmaceutical InNovation Under The \\ HATCH-WAXMAN ACT................................................... 266 \\ IV. The Myth Of Generic COMPetition Under THE \\ HATCH-WAXMAN ACT ...............................................276

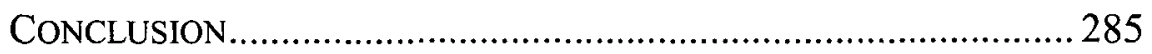

\section{INTRODUCTION}

By all reports, the outlook for the brand-name pharmaceutical industry ("brand name pharma") in the United States is surprisingly bleak. ${ }^{\prime}$ Brand-name pharmaceutical manufacturers develop innovative new drugs, but recently the pipeline for new

\footnotetext{
Associate Professor and Dean's Fellow, Indiana University School of LawIndianapolis. Many thanks to Max Huffman, Rob Katz, Jim Kelley, Andy Klein, David Orentlicher, Mike Pitts, Antony Page, Florence Roisman, Carlton Waterhouse, and to the participants at the Second Asia-Pacific Innovation Conference at the National University of Singapore, and the participants at the 2d Annual Developing Ideas Conference at the University of Kentucky College of Law. Special thanks to Chris Powers, Indiana University School of Law-Indianapolis ' 10 , for his exceptional research assistance.

1 See, e.g., BioJobBlogger, Why Generic Drug Companies Will Dominate Future Pharmaceutical Markets, BIOJOBBLOG (Feb. 1, 2010), http://www.biojobblog.com/20 10/02/articles/biobusiness/why-generic-drug-companies-will-dominate-future-pharma ceutical-markets/; Zacks Equity Research, Pharmaceutical Stock Outlook-Sept. 2011, ZACKS (Sept. 22, 2011), http://www.zacks.com/commentary/18914/Pharmaceutical+ Stock+Outlook.
} 
pharmaceutical agents has been drying up. ${ }^{2}$ Brand-name pharma is expected to produce very few new drugs in the near future. ${ }^{3}$ Indeed, companies like AstraZeneca have completely forgone some areas of drug development such as psychiatric drugs, focusing instead on more profitable areas such as cardiology and oncology. ${ }^{4}$ Eli Lilly, another giant in the industry, has slashed thousands of jobs, and consolidations and mergers among industry players are an increasingly common occurrence. ${ }^{5}$ American health care providers face shortages of much needed vaccines and medications because too few manufacturers are able to sustain a presence in those markets. ${ }^{6}$ The U.S. pharmaceutical industry was known until very recently, however, as one of the most robust and profitable in the world ${ }^{7}$ - what happened to cause this once flourishing industry to become one struggling to survive?

A variety of factors account for the rather sudden downturn in the fortunes of pharmaceutical manufacturers, including rapidly rising costs, decreasing profits, and the changing nature of pharmaceutical research. ${ }^{8}$ One issue seldom addressed, however, is the role of the Drug Price Competition and Patent Term Restoration Act, known informally as the Hatch-Waxman Act after

2 See BIOJOBBLOGGER, supra note 1.

3 Bernard Munos, Lessons from 60 Years of Pharmaceutical Innovation, 8 NATURE REVS. 959, 965 (2009).

4 See Ben Hirschler, RPT-UPDATE 1-AstraZeneca Drops Psychiatric, Other Drug Research, REUTERS (Mar. 2, 2010, 11:05 AM), http://www.reuters.com/article/2010 /03/02/astrazeneca-rd-idUSLDE62019Q20100302.

$5 \quad$ Mike Corbin, Eli Lilly Continues Layoffs Despite Profit, WISHTV8.COM (May 7, 2010, 4:29 PM), http://www.wishtv.com/dpp/news/business/eli-lilly-continues-layoffsdespite-profit-; Preston Henske \& Tim van Biesen, Mega Mergers Can't Cure the Pharmaceutical Industry, BLOOMBERG BuSINESSWEEK (July 26, 2009, 8:50 PM), http://www.businessweek.com/technology/content/jul2009/tc20090724_243995.htm.

6 Provisional Observations on Drug Product Shortages: Effects, Causes, and Potential Solutions, 59 AM. J. HeALTh-SYS. PhARM. 2173, 2173, 2179 (2002), available at http://www.ashp.org/s_ashp/docs/files/DShort_11b-SF-Witmer.pdf.

7 See Zacks Equity Research, Pharmaceutical Industry Outlook-March 2011, ZACKS (Mar. 2, 2011), http://www.zacks.com/stock/news/48376/Pharmaceutical+Industry+ Outlook.

${ }^{8}$ See Global Pharmaceutical R\&D Productivity Declining According to Thompson Reuters, CMR International, THOMSON REUTERS (July 1, 2010), http://thomsonreuters .com/content/press_room/science/RandD-Productivity-Declines. 
its two leading sponsors, ${ }^{9}$ in the current decline of brand-name pharma. Enacted in 1984 and amended in $2003,{ }^{10}$ this statutory scheme roughly coincides in time with brand-name pharma's drastic change in fortune. ${ }^{11}$ The question is whether anything more than mere coincidence underlies this connection.

The Act was designed to balance two countervailing tasks: facilitating greater market entry of lower-priced generic imitations of brand-name drugs, while at the same time preserving brandname pharma's incentives to continue discovering and developing new drugs. ${ }^{12}$ In retrospect, the Act appears to have been largely a success in its first goal but of questionable effect in its second. This Article takes a closer look at how the Hatch-Waxman Act may have impacted pharmaceutical innovation in the last three decades and, in particular, what role the Act may have played in the weakening of the U.S. brand-name pharma. This critical overview of the Act strongly suggests that it did indeed at least aggravate the industry's downward turn and, in any event, certainly did little to protect the continued vitality of the industry. ${ }^{13}$ We may therefore wish to reconsider the wisdom of maintaining the Act in its current form, or at all.

The analysis below suggests that the Hatch-Waxman Act focuses far too much on competition and on removing barriers to market entry - and in particular, on removing barriers to entry by generic pharmaceuticals - as a way of decreasing pharmaceutical

9 The Drug Price Competition and Patent Term Restoration Act of 1984, Pub. L. No. $98-417,98$ Stat. 1585 (1984).

10 Medicare Prescription Drug, Improvement, and Modernization Act of 2003, Pub. L. No. 108-173, 117 Stat. 2066 (2003) (amending the Hatch-Waxman Act).

11 Natalie M. Derzko, The Impact of Recent Reforms of The Hatch-Waxman Scheme on Orange Book Strategic Behavior and Pharmaceutical Innovation, 45 IDEA 165, 250-51 (2005).

12 Alfred B. Engelberg, Special Patent Provisions for Pharmaceuticals: Have they Outlived Their Usefulness?, 39 IDEA 389, 389 (1998-99) ("The Drug Price Competition and Patent Term Restoration Act of 1984 . . . was an unprecedented attempt to achieve two seemingly contradictory objectives, namely, 1) to make lower-costing generic copies of approved drugs more widely available and 2) to assure that there were adequate incentives to invest in the development of new drugs.").

13 See Matthew J. Higgins \& Stuart J. H. Graham, Balancing Innovation and Access: Patent Challenges Tip the Scales, 326 SCIENCE 370, 370 (2009) (suggesting that HatchWaxman has contributed to a decrease in the number of new drugs developed). 
costs for consumers. A sui generis regime that focuses solely on the pharmaceutical industry because of its singular regulatory burdens as well as its unique dependence on patents, the Act attempts to compensate for the fact that both regulation and patent protection can deter market entry. The Hatch-Waxman Act therefore promotes generic market entry by relieving almost all of the regulatory burdens for generic manufacturers, as well as by helping generic manufacturers challenge the validity of brandname pharmaceutical patents that might be hindering such market entry. ${ }^{14}$ Brand-name manufacturers, by contrast, enjoy no relief from heavy regulatory burdens. ${ }^{15}$ They can, however, ask for extensions on their pharmaceutical patent terms, as well as for short periods of regulatory exclusivity, as a means of offsetting those burdens. ${ }^{16}$

The Act fails to strike the right balance between these two sectors of the industry. It overshoots the mark in terms of fostering generic market entry while simultaneously undershooting the mark in terms of protecting brand-name pharma's incentives to develop new drugs. Even after Hatch-Waxman's attempt to restore patent duration to its full-expected term, the average effective life of a pharmaceutical patent is still shorter than that for any other type of patent. ${ }^{17}$ It is also too short to recoup the costs of developing and marketing the patented drug. ${ }^{18}$ Furthermore, Hatch-Waxman also subjects pharmaceutical patents to a level of challenge that no other type of patent faces, shortening the average effective lives of these patents even further. ${ }^{19}$ Given the incredible costs of

\footnotetext{
14 See infra part II.

15 See id.

16 See generally infra part II; Dana P. Goldman et. al., The Benefits from Giving Makers of Conventional 'Small Molecule' Drugs Exclusivity Over Clinical Trial Data, 30 HEALTH AFFaIRS 84 (2001).

17 Bruce N. Kuhlik, The Assault on Pharmaceutical Intellectual Property, 71 U. CHI. L. REv. 93, 96-97 (2004).

18 See Goldman et al., supra note 16, at 84-85 (The National Academies Committee on Science, Engineering, and Public Policy is unsure that an exclusivity period of ten to eleven years would be an adequate period of time given complexity and drug development today).

19 Henry G. Grabowski \& Margaret Kyle, Generic Competition and Market Exclusivity Periods in Pharmaceuticals, 28 Managerial \& DeCISION ECON. 491, 501 (2007).
} 
developing and marketing new drugs, not to mention the regulatory burdens of doing so, brand-name pharma is widely believed to depend on patent protection more than other industries. ${ }^{20}$ HatchWaxman's effective weakening of pharmaceutical patents may therefore have a devastating effect on this sector of the industry.

More importantly, by focusing almost exclusively on generic market entry and on brand-name patents as potential barriers to that entry, the Hatch-Waxman Act neglects the larger context of the pharmaceutical market. As a sui generis regime, the Act was implemented because pharmaceutical manufacturers do not function within a freely competitive market. Indeed, pharmaceuticals do not operate in a "true" market at all, for too many intervening factors, including third-party payors, physicians, pharmacies, marketing restrictions, regulatory exclusivities, and government subsidies, skew the economic dynamics that would normally be at play in a market system. ${ }^{21}$ It is therefore puzzling that the fundamental belief running throughout the Hatch-Waxman Act is that, to lower the cost of drugs, the Act can now suddenly introduce competition into the pharmaceutical market. ${ }^{22}$ Competition may be key to lowering costs in other parts of the health care system, and it may even be useful to a limited extent in lowering the cost of drugs. In this instance, however, the story is much more complex than the Act's narrow focus on generic market entry would lead one to believe.

Even assuming it was possible to address all the factors necessary to convert the pharmaceutical market into a potentially competitive one, simply focusing on generic regulatory burdens or

20 See Mark Schankerman, How Valuable Is Patent Protection? Estimates by Technology Field, 29 RAND J. ECON. 77, 78 (1998).

21 See Frank A. Sloan \& Chee-Ruey Hsieh, Introduction, in PHARMACEuTICAL INNOVATION: INCENTIVES, COMPETITION, AND COST-BENEFIT ANALYSIS IN INTERNATIONAL Perspective 1, 2-3 (Frank A. Sloan \& Chee-Ruey Hsieh eds., 2007).

22 See Applications for FDA Approval to Market a New Drug: Patent Listing Requirements and Application of 30-Month Stays of Approval of Abbreviated New Drug Applications Certifying That a Patent Claiming a Drug Is Invalid or Will Not be Infringed, 67 Fed. Reg. 65448, 65448 (proposed Oct. 24, 2002) (codified at 21 C.F.R. pt. 314) (stating that introducing pharmaceutical competition was the fundamental belief). See also generally Janet A. Gongola, Note, Prescriptions for Change: The HatchWaxman Act and New Legislation to Increase the Availability of Generic Drugs to Consumers, 36 IND. L. REv. 787 (2003). 
pharmaceutical patents would do little or nothing to foster any meaningful, long-term competition. As a first matter, it is not patents that separate brand-name pharmaceutical manufacturers from generic manufacturers, and it is not patents that determine brand-name pharmaceutical prices. Nor is it efficiency or other competitive advantages that allow generic manufacturers to market their drugs at much lower prices than brand-name manufacturers do. Rather, what separates brand-name and generic manufacturersand the prices at which they market their respective drugs-is the additional goods and services that brand-name manufacturers, and only brand-name manufacturers, provide along with each pharmaceutical that they sell. ${ }^{23}$ These additional goods and services include clinical trials data, post-marketing studies, and even physician and patient education. ${ }^{24}$ They are not simply added value niceties; they are essential to the safety and efficacy of pharmaceutical agents. ${ }^{25}$ As such, the Hatch-Waxman Act's single-minded fixation on generic manufacturers as if they were direct competitors for brand-name pharma is misguided at best.

That is not to say that the Hatch-Waxman Act has achieved no successes. In the short term, for instance, the Act allowed generic pharmaceuticals rapidly to acquire a much greater market share than they ever had before and to provide less expensive versions of thousands of drugs that used to be available only as higher-priced brand-name versions. ${ }^{26}$ The static social welfare gains from greater generic entry under the Act have therefore been significant. $^{27}$

In the longer-term, by contrast, the Act has done little to help brand-name manufacturers and their ability to continue to develop new pharmaceuticals. In fact, it has likely made their situation

\footnotetext{
23 See Sloan \& Hsieh, supra note 21 , at 4, 6 .

24 See id.

25 See Postmarketing Clinical Trials, FDA, http://www.fda.gov/BiologicsBlood Vaccines/GuidanceComplianceRegulatoryInformation/Post-MarketActivities/Phase4 Trials/default.htm (last updated Apr. 1, 2011).

26 Atanu Saha et al., Generic Competition in the US Pharmaceutical Industry, 13 INT. J. ECON. Bus. 15, 33-35 (2001).

27 See generally Hughes et al., "Napsterizing" Pharmaceuticals: Access, Innovation, and Consumer Welfare, (Nat'l Bureau of Econ. Research, Working Paper No. 9229, 2002), available at http://www.nber.org/papers/w9229.
} 
worse. $^{28}$ This in turn may decrease overall social welfare, as the continued development of drug therapies is thought to contribute greatly to social welfare. ${ }^{29}$ The dynamic social welfare effect of the Hatch-Waxman Act may therefore be quite negative. ${ }^{30}$ Accordingly, we should evaluate other approaches to the problems facing the pharmaceutical industry, such as market or data exclusivities.

The discussion proceeds as follows. Part I provides a brief summary of the pharmaceutical industry, the requirements for regulatory approval for marketing pharmaceuticals, and how patent protection subsidizes the entire enterprise. Part II then introduces the Hatch-Waxman Act, and Part III analyzes the effects of the Act within the industry, including its functional weakening of pharmaceutical patents. Widening the analysis, Part IV then critiques the fundamental assumptions driving the Hatch-Waxman Act, demonstrating how it imperils continued pharmaceutical innovation.

\section{The Pharmaceutical IndUSTRY: A PRIMER}

Pharmaceuticals are one of the most cost- and time-intensive areas of technological innovation as well as one of the industries most subject to regulatory intervention. ${ }^{31}$ Unlike most other technologies, pharmaceuticals are heavily regulated by the Food and Drug Administration ("FDA") to ensure their safety and efficacy; indeed, the FDA regulates the manufacture and marketing of pharmaceuticals more strictly than it regulates food, dietary

28 See Henry Grabowski, Competition Between Generic and Branded Drugs, in Pharmaceutical InNovation: InCEnTIVes, Competition, and Cost-Benefit Analysis IN INTERnational Perspective 153, 164-67 (Frank A. Sloan \& Chee-Ruey Hsieh eds., 2007); see also James W. Hughes et al., supra note 27 (citing legislative history anticipating this effect).

29 See, e.g., Frank Lichtenberg, Are the Benefits of Newer Drugs Worth Their Cost? Evidence from the 1996 MEPS, 20 HEALTH AFFAIRS 241, 241 (2001).

30 See generally Hughes et al., supra note 27.

31 See Michael Dickson \& Jean Paul Gagnon, Key Factors in the Rising Cost of New Drug Discovery and Development, 3 NATURE REVS. 417, 417 (2004). 
supplements, or cosmetics. $^{32}$ Identifying a compound with possible therapeutic benefits is only the first of many slow and incredibly expensive steps, and the cost of discovering, testing, and marketing new drugs is extremely high and continues to rise. ${ }^{33}$ As such, it is not surprising that pharmaceuticals are also widely recognized as one of the industries most dependent on patent protection to recoup its enormous research, development, regulatory, and post-marketing costs. ${ }^{34}$

The types of pharmaceuticals most common in the last several decades and addressed in the Hatch-Waxman Act are largely small-molecule compounds, which are relatively simple chemical compounds that can usually be manufactured using standard chemistry techniques. ${ }^{35}$ They thus differ in many important respects from the new wave of so-called "biologic" therapeutics, which are larger, more complex, and more difficult to manufacture. $^{36}$ Despite their comparative simplicity, however, small-molecule drugs are surprisingly time-consuming to invent. Widely accepted descriptions of the research and development process establish that it takes anywhere from three to six years merely to identify a chemical compound as a good candidate for further testing. ${ }^{37}$ This initial screening process, usually performed using animal or laboratory models, is time-intensive because of the volume of compounds that must be screened to identify just a few likely candidates; for every five to ten thousand compounds screened, only one to five compounds are identified. ${ }^{38}$ With the

\footnotetext{
32 See Nina J. Crimm, A Tax Proposal to Promote Pharmacologic Research, to Encourage Conventional Prescription Drug Innovation and Improvement, and to Reduce Product Liability Claims, 29 WAKE FoREST L. REV. 1007, 1020-22 (1994).

33 See id. at 1033-39.

34 Henry Grabowski, Pharmaceuticals: Politics, Policy and Availability: Patents and New Product Development in the Pharmaceutical and Biotechnology Industries, 8 Geo. PuB. Pol'y REv. 7, 8 (2003).

35 See Krista Hessler Carver et al., An Unofficial Legislative History of the Biologics Price Competition and Innovation Act of 2009, 65 FOOD \& DRUG L.J. 671, 735 (2010).

36 See Biologics, Biosimilars, and Generics: Anticipating the Biosimilar Challenge, ANALYSIS GROUP, http://www.analysisgroup.com/anticipating_biosimilar_challenge.aspx (last visited Nov. 4, 2011).

37 See Crimm, supra note 32, at 1019-20; Henry Grabowski, Health Reform and Pharmaceutical Innovation, 24 SETON HaLl L. Rev. 1221, 1234-35 (1994)

38 See Grabowski, supra note 34, at 1234-35.
} 
advent of more sophisticated screening methods, however, at least this part of the pharmaceutical research and development ("R\&D") process has possibly become less time-consuming.

From this initial screening stage, the compounds enter into the clinical trials phase of the development process, a step required to demonstrate the kind of safety and efficacy necessary to gain regulatory approval from the FDA. ${ }^{40}$ The three clinical trials phases move the compounds from animal and laboratory testing to actual human testing, an extremely delicate undertaking. ${ }^{41}$ As the public has become increasingly concerned about potential abuses, the FDA has exponentially increased the number of safeguards that must be in place while testing on humans. ${ }^{42}$ Implementing these safeguards is expensive and time-consuming, as is locating adequate numbers of human volunteers to participate in the testing. ${ }^{43}$ Trials often necessitate an enrollment of several thousand patients, all of whom require careful monitoring and other procedures to ensure their safety and the efficacy of the trial. $^{44}$ Current estimates suggest that clinical testing of new drugs requires anywhere from two to ten years, with an average of about five to six years in duration. ${ }^{45}$ Since 1980 , the average number of clinical trials conducted prior to filing for approval from the FDA has more than doubled, and the number of patients in clinical trials has tripled. ${ }^{46}$

\footnotetext{
39 See Arti K. Rai, The Information Revolution Reaches Pharmaceuticals: Balancing Innovation Incentives, Cost, and Access in the Post-Genomics Era, 2001 U. ILL. L. REV. 173, 189-92 (2001).

$40 \quad$ Id. at 181 n. 27 .

41 Id. at 181.

42 See Crimm, supra note 32, at 1020-26; see also Running Clinical Trials, FDA, http://www.fda.gov/ScienceResearch/SpecialTopics/RunningClinicalTrials/default.htm (last updated Sept. 14, 2011).

43 See Crimm, supra note 32, at 1024.

44 See id; Joseph A. DiMasi et al., The Price of Innovation: New Estimates of Drug Development Costs, 22 J. HealTh ECON. 151, 156 (2003).

45 See Rai, supra note 39, at 181 n.29.

46 See Oliver Gassmann et al., Leading Pharmaceutical Innovation: Trends AND DRIVERS FOR GROWTH IN THE PHARMACEUTICAL INDUSTRY 64 ( $2 \mathrm{~d}$ ed. 2008); see also Gregory J. Glover, Pharm. Research and Mfrs. of Am., Statement Before the Federal Trade Commission and the Department of Justice-Antitrust Division: Competition in the Pharmaceutical Marketplace, 4 (Mar. 19, 2002).
} 
Moreover, unlike the initial screening process, clinical testing costs have risen sharply because now more drugs are being studied to treat chronic diseases, which greatly multiplies the complexity of the trials and the difficulty of recruiting subjects. ${ }^{47}$ Clinical testing further narrows the field of potentially usable candidate drugs (chemical compounds); usually all but one or two are eliminated. ${ }^{48}$ The remaining compounds are then submitted to the FDA for approval via a New Drug Application ("NDA"). ${ }^{49}$ The FDA's approval process can run from months to years depending on the drug, but during the period from 1993-2003, the FDA approval process had a median length of approximately 15 months. ${ }^{50}$ The FDA has made a concerted effort to improve the efficiency and speed of the approval process, but public pressure to ensure that only safe and effective drugs are approved limits how quickly the FDA can review NDAs. ${ }^{51}$

All told, the average time needed from the initial synthesis and screening process through to FDA approval has increased significantly over the years, rising from 8.1 years in 1960 , to 11.6 years in the $1970 \mathrm{~s}$, to 14.2 years in the $1980 \mathrm{~s}$ and $1990 \mathrm{~s}^{52}$ Similarly, the average cost to develop a new drug is estimated to run from $\$ 802$ million to $\$ 1.2$ billion and rising, as the clinical trials necessary for FDA approval have increased in size and duration while the percentage of candidate drugs that pass testing has decreased. ${ }^{53}$ In the last three decades or so, the overall cost of developing new pharmaceuticals has increased greatly, with no

\footnotetext{
47 See Dickson \& Gagnon, supra note 31, at 417-18.

48 See GASSMANN ET AL., supra note 46, at 11; Grabowski, supra note 3, at 1234-35.

49 Crimm, supra note 32, at 1025.

so Fast Track, Accelerated Approval and Priority Review: Accelerating Availability of New Drugs for Patients with Serious Diseases, FDA, http://www.fda.gov/forconsumers/ byaudience/forpatientadvocates/speedingaccesstoimportantnewtherapies/ucm 128291 .htm (last updated May 28, 2010).

51 See id.; New Drug Development and Review Process, FDA, http://www.fda.gov/

Drugs/DevelopmentApprovalProcess/SmallBusinessAssistance/ucm053131.htm (last updated Nov. 1, 2011).

52 Dickson \& Gagnon, supra note 31 , at 418 ; Glover, supra note 46 , at 3-4.

53 See DiMasi et al., supra note 44, at 180-81; Efthimios Parasidis, Patients over Politics: Addressing Legislative Failure in the Regulation of Medical Products, 2011 WIS. L. REv. 929, 995 (2011) (and sources cited therein).
} 
obvious slow-down expected in the near future. ${ }^{54}$ As a result, R\&D costs alone are outstripping returns. Even before the HatchWaxman Act, the typical pharmaceutical innovator earned returns only $2 \%-3 \%$ over competitive returns. ${ }^{55}$ Given that pharmaceutical R\&D spending is tightly correlated with the expected returns on those investments, ${ }^{56}$ there is cause to worry that both long-term R\&D spending and pharmaceutical innovation may decrease in turn.

To make matters worse, a fact not mentioned by most commentators is that the cost of marketing new pharmaceuticals does not stop there. First, even after a new pharmaceutical has been approved for marketing, the FDA often requires that the manufacturer continue monitoring its use for additional information about its safety, efficacy, or optimal use. ${ }^{57}$ These "post-marketing commitment" or "Phase IV" studies often cost a brand-name pharmaceutical company another twenty to thirty million dollars. ${ }^{58}$ Second, and closely related to the first, new pharmaceuticals frequently require large marketing and education investments in order to introduce physicians, hospital formularies, pharmacies, and insurers to the new drug and to educate them about the drug's benefits and risks, how to use it safely, what new information has been gathered about the drug, and so on. ${ }^{59}$ Without investments in thus "detailing" a new drug to physicians and others, the sales of the drug would likely languish for many years. This would further impair the manufacturer's ability to

\footnotetext{
54 See DiMasi et al., supra note 44, 180-82.

55 See F.M. Scherer, Pricing, Profits, and Technological Progress in the Pharmaceutical Industry, 7 J. ECON. PERSP. 97, 105 (1993).

56 DiMasi et al., supra note 44, at 182-83.

57 Rebecca S. Eisenberg, The Role of the FDA in Innovation Policy, $13 \mathrm{MiCH}$. TELECOMM. TECH. L. REV. 345, 376 (2007).

58 See Charles Steenburg, The Food and Drug Administration's Use of Postmarketing (Phase IV) Study Requirements: Exception to the Rule? 61 FoOD \& DRUG L.J. 295, 370 (2006).

59 See Richard E. Caves et al, Patent Expiration, Entry, and Competition in the U.S. Pharmaceutical Industry, 1991 BrookInGS PAPERS on ECON. ACTIVITY Microeconomics 1, 3, 11-12 (1991); see also Competition and Regulation Issues in the Pharmaceutical Industry, OECD at 30 (2000), http://www.oecd.org/dataoecd/35/35/1920 540.pdf (estimating that the U.S. pharmaceutical industry spends at least $\$ 5$ billion per year on promotions).
} 
recoup its investment in the drug. Indeed, pharmaceutical sales representatives are usually the first to provide physicians with new information about a drug and are often important in keeping physicians current about the latest developments in medical diagnosis and treatment. ${ }^{60}$ Such promotion investments thus create significant positive externalities well beyond any increase in sales they might garner. ${ }^{61}$ Despite popular perception, moreover, such social welfare-creating, product-specific educational expenditures constitute the vast majority of overall pharmaceutical promotion spending, as compared to direct-to-consumer advertising or advertising to promote general goodwill toward the pharmaceutical manufacturer. $^{62}$

Finally, a third and rapidly growing cost of pharmaceutical innovation is product liability. In recent years, the number of lawsuits against pharmaceutical companies alleging product liability has outpaced those of just about any other industry, as have the average damages awards in these cases. ${ }^{63}$ Most of these cases involve allegations of failure to warn of the possible adverse effects of the drugs, including effects of unapproved, "off-label" uses. $^{64}$ In all, these combined post-marketing costs also add to the costs of developing new pharmaceuticals.

How does brand-name pharma fund the incredibly expensive and time-consuming drug development and marketing processes? Although the full explanation is somewhat more complicated, for private brand-name pharma the answer is mostly patents. A patent is an intellectual property right to exclude all others from making,

60 See Susan Heilbronner Fisher, The Economic Wisdom of Regulating Pharmaceutical "Freebies", 1991 DUKE L.J. 206, 219 (1991).

61 See id. at 219 (citing Marilyn Y. Peay \& Edmund R. Peay, Differences Among Practitioners in Patterns of Preference for Information Sources in the Adoption of New Drugs, 18 Soc. SCI. MED. 1019 (1984)).

62 Id. at 209-10.

63 See Office of Tech. Assessment, U.S. Cong., Pharmaceutical R\&D: Costs, RISKS AND REWARDS, OTA-H-522 169-82 (1993), available at http://www.fas.org/ota/reports/9336.pdf; Joseph Mercola, The Avalanche of Pharmaceutical Lawsuits, MERCOLA.COM (Sept. 5, 2006), http://articles.mercola.com/ sites/articles/archive/2006/09/05/the-avalanche-of-pharmaceutical-lawsuits.aspx.

${ }^{64}$ See James O'Reilly \& Amy Dalal, Off-Label or Out of Bounds? Prescriber and Marketer Liability for Unapproved Uses of FDA-Approved Drugs, 12 ANNALS HEALTH L. 295, 315 (2003). 
selling, using, or offering to sell one's patented invention for a period of twenty years from the date of filing for the patent. ${ }^{65}$ Thus, on its face, patents seem like the ideal way for brand-name pharma to protect its investment in inventing new drugs, and in many ways they are. The patent system is designed to incentivize investments in R\&D of new technologies--investments which are certainly pivotal to pharmaceutical innovation. ${ }^{66}$ This kind of protection can therefore be particularly important for socially useful inventions such as pharmaceuticals, which are expensive to develop but quite inexpensive to copy. ${ }^{67}$ Indeed, a number of studies have produced robust data suggesting that pharmaceuticals, above all other areas of science and technology, value their patents. ${ }^{68}$ This is thought to be attributable in large part to the fact that the traditional small-molecule drug is a single chemical entity that, unlike electronics, can usually be covered by a single patent (although patents for methods of producing or using the drug or on variations of the drug are also possible). ${ }^{69}$ Marketing of a smallmolecule drug therefore does not require the kind of coordination of multiple patents and multiple patent holders often seen in other industries. ${ }^{70}$ By using a patent to exclude all others from making, using, or selling a new drug while garnering all the returns on that drug to oneself, a brand-name pharmaceutical innovator could recoup enough profit to cover its huge $\mathrm{R} \& \mathrm{D}$ outlays.

The value of pharmaceutical patents, however, is complicated by the fact that new pharmaceutical compounds must go through so many years of testing while the terms of their patents tick away. Pharmaceutical companies customarily apply for "composition of

\footnotetext{
6535 U.S.C. $\$ 154(2006)$.

66 See U.S. CONST. art. I, § 8, cl. 8; Sloan \& Hsieh, supra note 21, at 1, 4.

67 See James Bessen \& Michael J. Meurer, Patent Failure: How Judges, BuREaUCRATS, AND LaWYers Put INNOVATORS AT Risk 88-89 (2008).

68 See Derzko, supra note 11, at 251 n.446 (citing Edwin Mansfield, Patents and Innovation: An Empirical Study, 32 MGT. SCI. 173 (1986); Ronald C. Levin et al., Appropriating the Returns from Industrial Research and Development, 3 BROOKINGS PAPERS ON ECON. ACTIVITY 783, 796 (1987)).

69 See, e.g., Rebecca S. Eisenberg, The Shifting Functional Balance of Patents and Drug Regulation, Health AffaIRS, 119, 119-20 (2001); Valerie Junod, Drug Marketing Exclusivity Under United States and European Union Law, 59 Food \& Drug L.J. 479, 486 (2004).

70 See BESSEN \& MEURER, supra note 67, at 106-07; Glover, supra note 46, at 8.
} 
matter" patents, the strongest type of protection for new chemical entities, soon after the initial non-clinical screening process, shortly before clinical testing in humans. ${ }^{71}$ This means that the maximum twenty-year patent term is ticking away while the drug goes through the clinical testing and FDA approval processes and the patent application goes through the patent examination process. $^{72}$ Thus, by the time a pharmaceutical patent holder can actually begin marketing a new drug to begin earning returns on it, the patent on the new drug often has only a few years of duration left. ${ }^{73}$ Moreover, sales of a new drug after FDA approval will often lag as the manufacturer educates health-care providers and the public about it. ${ }^{74}$ This is especially true if a new drug is the first in its therapeutic or even chemical category. ${ }^{75}$ Most drugs do not start to earn positive marginal returns until about the sixth year on the market, which leaves even fewer years of patent exclusivity to capture meaningful returns that can compensate for the fixed overall costs of bringing the new drug to market. ${ }^{76}$

Furthermore, simply owning a patent on a new drug is no guarantee of meaningful market exclusivity. ${ }^{77}$ Many drugs enter therapeutic markets already crowded with non-infringing

7 See Glover, supra note 46, at 3-5; Gerald J. Mossinghoff, Overview of the HatchWaxman Act and Its Impact on the Drug Development Process, 54 FOOD \& DRUG L.J. 187,192 (1999).

72 See id. at 192.

73 See Eisenberg, supra note 57, at 348; Henry Grabowski \& John Vernon, Longer Patents for Increased Generic Competition in the US: The Waxman-Hatch Act after One Decade, 10 Pharmacoeconomics 110,119 (1996) [hereinafter Grabowski \& Vernon, Longer Patents].

${ }_{74}$ See Sloan \& Hsieh, supra note 21, at 1, 6 (typically, pharmaceutical firms will aim their marketing efforts at physicians who then prescribe the firm's drugs to their patients). 75 See Ernst R. Berndt, The United States' Experience with Direct-to-Consumer Advertising of Prescription Drugs: What Have We Learned?, in PHARMACEUTICAL INNOVATION: INCENTIVES, COMPETITION, AND COST-BENEFIT ANALYSIS IN INTERNATIONAL PersPeCtive 174, 175 (Frank A. Sloan \& Chee-Ruey Hsieh eds., 2007); William S. Comanor, The Economics of Research and Development in the Pharmaceutical Industry, in Pharmaceutical InNovation: Incentives, Competition, and Cost-Benefit ANALYSIS IN INTERNATIONAL PERSPECTIVE supra, at 54, 59.

76 Henry G. Grabowski \& John M. Vernon, Effective Patent Life in Pharmaceuticals, 19 INT'L J. TECH. MGMT. 98, 101 (2000) [hereinafter Grabowski \& Vernon, Effective Patent Life].

77 Cf. Illinois Tool Works Inc. v. Independent Ink, Inc., 547 U.S. 28, 32 (2006) (noting that patents do not guarantee market power); Glover, supra note 46, at 6-7. 
alternatives, including alternatives very similar in effect and composition to the new drug. And if the market is not crowded at entry, it soon will be, as competitors develop their own noninfringing "me-too" versions of the new drug. ${ }^{78}$ Yet other drugs treat patient bases that are not nearly large enough to yield returns adequate to compensate for their R\&D costs. ${ }^{79}$ In fact, only $30 \%$ of marketed drugs ever earn enough profit to cover their average development costs. ${ }^{80}$ With increasing development time and costs, in the future even fewer new drugs will be able cover their development costs. As a result, brand-name pharma is forced to rely upon the few blockbuster drugs that do earn significant returns in order to subsidize the development and marketing of the other drugs they develop, many of which bring great social welfare but little profit. ${ }^{81}$ Accordingly, even large and highly diversified brand-name companies must develop a flagship drug every two to three years or risk huge losses. ${ }^{82}$

Not surprisingly, the pharmaceutical patents on the few superstar flagship drugs are extremely valuable, for they are the few mainstays that support the rest of the industry's activities. Brand-name manufacturers therefore routinely introduce new dosage formulations or other incremental and sequential innovations on these blockbuster drugs in order to continue profiting on them. ${ }^{83}$ While brand-name pharma defends this practice as enhancing patient outcomes, fostering competition within the marketplace, and generally expanding patient and physician choices, critics of this practice claim that brand-name pharma is merely trying to "evergreen" its original patents on the

\footnotetext{
78 See Grabowski \& Vernon, Effective Patent Life, supra note 76, at 102; Glover, supra note 46 , at 6-7.

79 See Glover, supra note 46, at 4-7.

80 Christopher Fasel, Patent Term Limits, Anti-Trust Law, and the Hatch-Waxman Act. Why Defense of a Legally Granted Patent Monopoly Does Not Violate Anti-Trust Laws, 17 KAN. J.L. \& PUB. POL'Y 109, 124 (2007) (citing In re Ciprofloxacin Hydrochloride Anti-Trust Litig., 261 F. Supp. 2d 188, 256 (E.D.N.Y. 2003)).

81 Grabowski \& Vernon, Effective Patent Life, supra note 76, at 102; Glover, supra note 46, at 4. The Orphan Drug Act and other types of targeted market exclusivities also provide limited incentives to develop beneficial but less profitable pharmaceuticals. See Derzko, supra note 11, at 263-64.

$82 \quad I d$

83 Id. at $7-8$.
} 
new drug and thereby unfairly extend its profits. ${ }^{84}$ There is plenty of reason to doubt that such sequential innovation patents are nearly as suspect as the critics would make out, particularly in light of the economic realities outlined above. Both Congress and the courts have grown increasingly skeptical of such strategies, however, further limiting the profitability of pharmaceutical innovation. ${ }^{85}$

\section{THE HATCH-WAXMAN ACT}

Into this morass of regulatory and economic pressures steps the Hatch-Waxman Act with its byzantine statutory scheme and affiliated amendments. Some of its provisions favor brand-name pharmaceutical innovators, largely by restoring part of any patent term lost during the development and regulatory approval process. ${ }^{86}$ A much more significant effect of the Act, however, is fostering generic pharmaceutical entry into the market with their typically much lower-price imitations of brand-name pharmaceuticals. $^{87}$

To compensate for some of the patent life lost during the FDA approval process, the Hatch-Waxman Act provides for restoration of patent term equal to one-half of the time period from the start of human clinical trials to NDA approval and all of the time spent during the NDA approval process itself. $^{88}$ A patented New Chemical Entity ("NCE") can receive up to five years of term restoration, so long as the total remaining patent life after extensions does not exceed fourteen years from the date of FDA marketing approval. ${ }^{89}$ Moreover, any single NCE can enjoy only

84 See id. at 7-8; Junod, supra note 69, at 495; John R. Thomas, Patent "Evergreening": Issues in Innovation and Competition, CONG. RESEARCH SERV., 1 (Nov. 13, 2009), http://ipmall.info/hosted_resources/crs/R40917_091113.pdf.

85 See id. at 6-7; Derzko, supra note 11, at 220-21.

86 See Frank R. Lichtenberg \& Tomas J. Philipson, The Dual Effects of Intellectual Property Regulations: Within- and Between-Patent Competition in the U.S. Pharmaceuticals Industry, 45 J.L. \& ECON. 643, 647 (2002).

87 Sarah E. Eurek, Hatch-Waxman Reform and Accelerated Market Entry of Generic Drugs: Is Faster Necessarily Better?, 2003 DuKE L. \& TECH. REV. 18, at *2 (2003).

88 John R. Thomas, Pharmaceutical Patent Law 17 (2005).

89 Id. (citing 35 U.S.C. $\$ 156(2006))$. 
one such patent term restoration, even if it is covered by multiple patents. ${ }^{90}$ The average effective patent life in other sciences and technologies is about seventeen years, after taking into account the average three-year interval the United States Patent and Trademark Office requires to examine and approve a patent application. ${ }^{91}$ Hatch-Waxman's partial restoration of a pharmaceutical patent's lost duration therefore helps to restore pharmaceutical patents to at least part of the average duration of other types of patents.

In addition, the Act grants NCEs five years of data exclusivity. ${ }^{92}$ This means that for five years after NCE approval, generic manufacturers or competitors seeking approval of their own pharmaceuticals may not rely on any clinical trial testing or other data generated by the NCE manufacturer. ${ }^{93}$ Given that the FDA requires extensive clinical testing and other data as proof of a drug's safety and efficacy, even if that drug is simply an imitation of another, approved drug, this five years of data exclusivity effectively means that an approved NCE enjoys a minimum of five years of market exclusivity, at least for the particular drug at issue. $^{94}$ This NCE data exclusivity applies, moreover, even if the NCE is not patentable or otherwise granted exclusivity. ${ }^{95}$ As mentioned above, however, this does not mean that any given NCE will not still face significant competition from other drugs, particularly those within the same therapeutic category, that have also been approved for marketing by the FDA. ${ }^{96}$ Nonetheless,

90 Merck \& Co., Inc. v. Kessler, 80 F.3d 1543, 1547 (Fed. Cir. 1996).

91 Indeed, before June 1, 1995, U.S. patent terms were set at seventeen years from date of issuance, rather than the current twenty years from date of application. The average effective patent term was therefore expected not to change.

92 See Kuhlik, supra note 17, at 98.

93 See id.

94 See id. at 98-99 (explaining how a generic competitor is prevented from filing an ANDA until five years after FDA approval of the brand name drug).

95 See 21 U.S.C. $\S 355(\mathrm{c})(3)(\mathrm{E})(\mathrm{ii)}$ (2006); see also Small Business Assistance: Frequently Asked Questions for New Drug Product Exclusivity, FDA, http://www.fda.gov/Drugs/DevelopmentApprovalProcess/SmallBusinessAssistance/ucm0 69962.htm (last visited Nov. 3, 2011); Kurt R. Karst, The Scope of New Chemical Entity Exclusivity and FDA's "Umbrella" Exclusivity Policy, FDA LAW BLOG (Jul. 20, 2011, 8:34 PM), http://www.fdalawblog.net/fda_law_blog_hyman_phelps/2011/07/the-scopeof-new-chemical-entity-exclusivity-and-fdas-umbrella-exclusivity-policy.html.

96 See supra notes 73-74 and accompanying text. 
NCE exclusivity does at least mean that for a short period of time, others cannot imitate a brand-name innovator's new drug or freeride on the clinical trials data on that drug. ${ }^{97}$

Other than patent term restoration and NCE data exclusivity, however, brand-name pharmaceutical innovators received few other concessions under Hatch-Waxman, a marked contrast to the benefits generic pharmaceutical manufacturers received. To foster greater generic entry into the pharmaceutical market, the HatchWaxman Act changed a variety of things. First and foremost, the Act changed the rule that in seeking marketing approval for their imitations of brand-name drugs, generic manufacturers could not rely on safety and efficacy data generated by the brand-name manufacturers. ${ }^{98}$ Prior to the Act, generic manufacturers had to generate their own safety and efficacy data for submission to the FDA, an often expensive and time-consuming proposition for the generic manufacturer that could delay or even deter its entry into the market. ${ }^{99}$ Since enactment of the Act, however, a generic manufacturer can now file what is known as an Abbreviated New Drug Application, or ANDA. ${ }^{100}$ ANDA applicants are not required to repeat the expensive and lengthy clinical trials previously demanded by the FDA, but instead may simply show that its product has the same active ingredient, route of administration, dosage form, strength, and labeling as the brandname NCE that it imitates. ${ }^{101}$ In stark contrast to the overall development cost of bringing an NDA on a new drug through FDA approval, the cost of preparing and filing an ANDA is only about $\$ 1$ million. ${ }^{102}$

Moreover, a generic manufacturer may now begin studying and experimenting with an NCE, in preparation for filing an ANDA on

\footnotetext{
97 See 21 U.S.C. $\$ 355(\mathrm{c})(3)(\mathrm{E})(\mathrm{ii)}$ (2006); FDA, supra note 91.

98 See 21 U.S.C \& 355(j) (2006); Susan Kopp Keyack, The Drug Price Competition and Patent Term Restoration Act of 1984: Is It A Healthy Long Term Solution?, 21 RUTGERS L.J. 147, 155 n.60 (1989).

99 See 21 U.S.C \& 355(j) (2006); Keyack, supra note 98, at 155 n.60.

100 See 21 U.S.C \$ 355(j) (2006).

101 See id.

102 C. Scott Hemphill \& Bhaven N. Sampat, When Do Generics Challenge Drug Patents?, 8 J. EMPIRICAL L. STUD. 613, 618 (2011) (and sources cited therein).
} 
it, even before any patent on the NCE has expired. ${ }^{103}$ This further speeds generic entry into the pharmaceutical market. Pre-HatchWaxman, generics had to wait until all patents expired on an NCE before beginning to generate the safety and efficacy data needed to file an NDA on its generic imitation of that NCE, which often delayed market entry until years after patent expiration. ${ }^{104}$ PostHatch-Waxman, by contrast, generics can now file ANDAs not only well before patent expiration, but also forgo the timeconsuming process of generating its own data. ${ }^{105}$ Indeed, under the Hatch-Waxman Act, a generic can file an ANDA as soon as four years after the original approval of the NCE the generic plans to imitate. ${ }^{106}$

As noted above, however, pharmaceutical patents are the bread and butter of brand-name pharma, and, even under HatchWaxman, generic manufacturers cannot simply sidestep patent rights altogether. Instead, Hatch-Waxman provides that generics filing ANDAs must certify whether the NCE drug they wish to imitate is: (i) not covered by any product patent listed by the original NCE applicant; (ii) that any such listed patents have expired; (iii) that any such listed patents, although still in force now, will expire by the time the generic plans to enter the market; or (iv) that any such listed patents on the NCE are invalid, not infringed by the generic, or both. ${ }^{107}$ These options, designated as Paragraph I, II, III, or IV certifications respectively, give both the FDA and any potential patent holders notice of the generic's intent. ${ }^{108}$

Paragraph IV certifications pose the most interesting problem. For a Paragraph I or II certification, the FDA may simply approve an ANDA as soon as it is satisfied that the product is safe and effective. $^{109}$ Likewise, for a Paragraph III certification, the FDA

\footnotetext{
103 See Thomas Chen, Authorized Generics: A Prescription for Hatch-Waxman Reform, 93 VA. L. REV. 459, 464 (2007).

104 See id. at 463 .

105 Id. at 464; Grabowski \& Kyle, supra note 19 at 491-92.

106 Id. at 492 (the period shrinks from five to four years when the applicant files a Paragraph IV certification).

10721 U.S.C. $\$ 355(\mathrm{j})(2)(\mathrm{A})(\mathrm{vii})(2006)$.

108 See id.; see also Mossinghoff, supra note 71, at 189-90.

109 See 21 U.S.C. $\$ 355(j)(5)(B)(2006)$.
} 
may simply grant approval as soon as any relevant patent expires. ${ }^{110}$ Paragraph IV certifications, on the other hand, establish that the FDA cannot approve the ANDAs at issue until all possible patent infringement or invalidity issues have been addressed in one form or another-a task that the FDA is unable to perform itself. ${ }^{11}$ The Hatch-Waxman Act therefore establishes that simply filing an ANDA with a Paragraph IV certification is an "artificial" act of infringement giving rise to a justiciable case or controversy, including a claim for declaratory judgment, under the Patent Act. ${ }^{112}$ This in turn gives the federal courts jurisdiction to address any conflicts over the relevant patents. ${ }^{113}$

Although most of the particulars of the consequent resolution process are more complex than need be discussed here, one additional detail demonstrates just how unique the pharmaceutical patents have become after the Hatch-Waxman Act was enacted. Lest the returns on the generic sales alone are not enough to induce a generic manufacturer to challenge an unexpired pharmaceutical patent, Hatch-Waxman provides that the first generic to file a Paragraph IV certification with regard to any given NCE may enjoy 180 days of market exclusivity as the only generic manufacturer of that particular drug. ${ }^{114}$ In other words, during the 180-day exclusivity period, the generic challenger and the brandname manufacturer of the NCE enjoy an effective duopoly with its potential for supracompetitive returns (although now, simultaneous Paragraph IV certifications may mean that multiple generics will have to share the 180 -day exclusivity). ${ }^{115}$ The 180 -day exclusivity period commences either on the date the generic first begins commercial marketing or on the date a court decides that the patent is in fact invalid or not infringed. ${ }^{116}$

\footnotetext{
110 See id.

11 See William E. Ridgway, Realizing Two-Tiered Innovation Policy Through Drug Regulation, 58 STAN. L. REV. 1221, 1227 (2006).

112 See 35 U.S.C. $\$ 271(\mathrm{e})(5)(2006)$; Engelberg, supra note 12, at 401-02. See also generally 21 U.S.C. $\$ 355$ (2006).

113 See Engelberg, supra note 12, at 402.

114 See id. at 391.

115 See 21 U.S.C. $\S 355(\mathrm{j})(5)(\mathrm{B})(\mathrm{iv})$ (2006); Kuhlik, supra note 17, at 97.

116 See 21 U.S.C. $₹ 335(\mathrm{j})(5)(\mathrm{B})(\mathrm{iv})$ (2006). The Medicare Prescription Drug, Improvement, and Modernization Act of 2003 established some rather complicated
} 
In terms of increasing generic entry, the Hatch-Waxman Act seems to be a huge success. Since the law's passage, the generic industry's share of the prescription drug market has jumped from just under twenty percent to just under fifty percent. ${ }^{117}$ Likewise, the number of generic drugs available jumped from just thirty-six percent of the top-selling brand-name drugs to virtually one hundred percent coverage of all such drugs. ${ }^{118}$ Before the enactment, generics had to spend at least three to five years after expiration of the brand-name manufacturer's patent to complete all the regulatory approval requirements necessary to market a generic imitation; today, generic entry occurs immediately upon patent expiration, if not sooner. ${ }^{119}$ Finally, and most importantly, generic entry has dramatically reduced the price of the affected drugs anywhere from forty to seventy percent of their brand-name prices. $^{120}$

Interestingly, defenders of the Hatch-Waxman Act seldom mention that at just about the same time as the enactment of the Act, both insurers and state laws also changed from discouraging or outright prohibiting generic substitution for prescriptions of brand-name drugs to encouraging or outright requiring such substitution. ${ }^{121}$ Insurers, hospitals, and the government also use pharmaceutical benefit managers, or "PBMs," to manage how pharmaceuticals are dispensed and to encourage whenever possible generic substitution for prescriptions of brand-name drugs, ${ }^{122}$ even

provisions forfeiting the 180 -day exclusivity if not commenced in a timely manner, but the effects of those amendments are yet to be seen. See C. Scott Hemphill, An Aggregate Approach to Antitrust: Using New Data and Rulemaking to Preserve Drug Competition, 109 COLUM. L. Rev. 629, 659 (2009).

117 See Wansheng Jerry Liu, Balancing Accessibility and Sustainability: How to Achieve the Dual Objectives of the Hatch-Waxman Act While Resolving Antitrust Issues in Pharmaceutical Patent Settlement Cases, 18 ALB. L.J. SCI. \& TECH. 441, 456 (2008).

118 See David A. Balto, Pharmaceutical Patent Settlements: The Antitrust Risks, 55 FoOD \& DRUG L.J. 321, 325 (2000).

119 See Glover, supra note 46 , at 7; Liu, supra note 117 , at 456.

120 See Scherer, supra note 51, at 101.

121 See Caves et al., supra note 59, at 6 (and sources cited therein); Kuhlik, supra note 17, at 95; see also David Reiffen \& Michael S. Ward, "Branded Generics" as a Strategy to Limit Cannibalization of Pharmaceutical Markets, 28 MANAGERIAL \& DECISION ECON. $251,255-56$ (2007) (attributing this in part to growth of HMOs).

122 See Grabowski, supra note 26, at 156; Kuhlik, supra note 17, at 95-96. 
if doing so means switching to an entirely different drug within the same therapeutic class. ${ }^{123}$ In fact, both PBMs and pharmacies have their own self-interests at heart when they do so: pharmacies are commonly offered higher dispensing fees for selling generics than for selling brand-name equivalents. ${ }^{124}$ Nevertheless, these latter changes probably account for only a portion of generic penetration into the pharmaceutical market. By all standards, the HatchWaxman Act appears to have achieved that part of its purpose well. But just how well has the Act simultaneously protected pharmaceutical innovation?

\section{PharmaceUtical INNOVATION UNDER THE HATCH-WAXMAN ACT}

Although the Hatch-Waxman Act was designed to balance brand-name pharma's incentives to continue developing new drugs with generic pharma's ability to enter the pharmaceutical market with low-price imitations of those drugs, we can already begin to see that the Act has failed to strike the right balance. As the discussion below demonstrates, the Act at the very least has failed to protect brand-name pharma's patent rights adequately and, indeed, likely weakens them even further. In addition, and perhaps more importantly, the Act focuses on what are likely the wrong factors - competition and the role of patents. As a result, the Act likely does more harm than good for pharmaceutical consumers in the long run.

First, although the Hatch-Waxman Act was designed in part to protect incentives to invest in pharmaceutical innovation and the development of new drugs, ${ }^{125}$ it appears to fail in that aim on at least three counts. On the first count, the Act fails to return pharmaceutical patents to the same status as other types of patents in terms of effective patent life. As explained above, the average

\footnotetext{
123 Lee G. Branstetter et al., Regulation and Welfare: Evidence from Paragraph IV Generic Entry in the Pharmaceutical Industry (Nat'l Bureau of Econ. Research, Working Paper No. 17188, 2011), available at http://www.nber.org/papers/w17188.

124 See Caves et al., supra note 59, at 6; Grabowski, supra note 28, at 156; Kuhlik, supra note 17, at 95-96.

125 See Engelberg, supra note 12, at 389.
} 
effective lifespan - the span of time during which the patented invention can actually be exploited commercially-is around eighteen and a half years for non-pharmaceutical patents, ${ }^{126}$ and is potentially even longer if the patent holder decides to market the invention before the patent on it has been granted, which patent holders often do. ${ }^{127}$ For pharmaceutical patents, by contrast, including even those that enjoy patent term restoration under Hatch-Waxman, the maximum effective lifespan is only fourteen years from the date the FDA approves the drug for marketing; ${ }^{128}$ no commercial exploitation of the drug may take place before that time. $^{129}$

This raises the second count on which Hatch-Waxman fails. Not only does it fail to restore the pharmaceutical patent term to the same duration as that for other types of patents, it also fails to restore the pharmaceutical patent term to that necessary to recoup the costs of developing patentable new drugs in the first place. As noted above, new drugs generally earn negative cumulative cash flow until at least the sixth year of marketing because of the huge launch expenditures in educating physicians, pharmacies, thirdparty payors, and patients about the new drug and the inevitable delays in learning about the new drug and how best to use it. ${ }^{130}$ Even after new drugs begin to earn a positive net return, economists have established that the new drugs do not typically accumulate enough of those positive returns to recoup their fixed costs for R\&D and clinical testing until at least the sixteenth year of marketing. ${ }^{131}$ This estimate is based on the fixed costs for producing drugs (approximately $\$ 202$ million) as they existed back in $1980 .{ }^{132}$ As mentioned above, however, the fixed costs of

\footnotetext{
126 See Daniel I. Gorlin, Staving off Death: A Case Study of the Pharmaceutical Industry's Strategies to Protect Blockbuster Franchises, 63 FOOD DRUG L.J. 823, 832 (2008); Kuhlik, supra note 17, at 96-97.

127 See Frequently Asked Questions About Patents, USPTO, www.uspto.gov/faq/ patents.jsp (last updated Mar. 30, 2011, 4:26:58 PM) (describing use of the term "patent pending" on products).

128 Mossinghoff, supra note 71, at 190.

129 Development \& Approval Process (Drugs), FDA, http://www.fda.gov/drugs/ developmentapprovalprocess/default.htm (last updated Oct. 27, 2009).

130 Grabowski \& Vernon, Effective Patent Life, supra note 76, at 100.

131 Id. at $100-01$.

$132 \mathrm{Id}$.
} 
developing new drugs, particularly the cost of clinical trials, have been increasing at a rapid rate, such that independent estimates of current fixed development costs now approach anywhere from $\$ 802$ million to $\$ 1.2$ billion. ${ }^{133}$ With the significant generic market entry that has occurred since the 1980s, thanks in large part to the Hatch-Waxman Act, as well as the various laws and policies now requiring generic substitution for prescriptions of brand-name drugs, the average effective patent life necessary for new drugs to recoup their fixed costs is likely far greater than the earlier estimate of sixteen years.

Thus, if the patents were truly to operate in compensating brand-name pharmaceutical innovators for the costs of developing new drugs, and thereby incentivize them to develop new drugs, effective pharmaceutical patent life would have to extend for at least sixteen years, if not more. In fact, at least one (admittedly stylized) analysis has suggested that, when measured in terms of not only brand-name pharmaceutical operating costs but also the overall social welfare that they create, the optimal effective patent life might be closer to eighteen or even nineteen years. ${ }^{134}$ By capping maximum patent term extensions to five years extension and only fourteen years total duration, the Hatch-Waxman Act clearly falls short of the mark.

Indeed, the Hatch-Waxman Act not only fails to extend effective pharmaceutical patent exclusivity to the duration necessary but also may fail to extend it at all. Consider the average effective patent exclusivity pre-Hatch-Waxman. Average pharmaceutical patent life just prior to the Act was only about eight years. ${ }^{135}$ As noted above, however, prior to the Act, generics manufacturers could not enter the market directly upon patent expiration. ${ }^{136}$ Instead, they had to wait until after patent expiration to perform their own time-consuming safety and efficacy studies, rather than simply free-riding on the data in the brand-name

\footnotetext{
133 Carver et al., supra note 35, at 735; Kuhlik, supra note 17, at 94.

134 Hughes et al., supra note 28, at 30-31.

135 Grabowski \& Vernon, Longer Patent Life, supra note 73, at 118; Grabowski \& Vernon, Effective Patent Life, supra note 76, at 103.

136 See supra text accompanying notes 103-05; see also Branstetter supra note 123, at 3; Eisenberg supra note 57, at 356-57; Gongola supra note 22, at 791-92.
} 
manufacturer's previously filed NDA. ${ }^{137}$ This process typically took another three to four years beyond patent expiration, thereby granting brand-name manufacturers a de facto three- to four-year extension on their patent exclusivity. ${ }^{138}$ Now compare this to pharmaceutical patent exclusivity after Hatch-Waxman. Despite the Act's patent term extension provisions, most pharmaceutical patents still enjoy an average effective lifespan of only eleven to twelve years at best, ${ }^{139}$ with patent-term extensions of only two to three years on average. ${ }^{140}$ Moreover, studies suggest that average effective patent life is declining even further over time, due in part to the growing length of clinical testing. ${ }^{141}$ In other words, any patent-term extensions that brand-name manufacturers might enjoy under Hatch-Waxman are generally offset by the Act's experimental-use exception and ANDA provisions, ${ }^{142}$ and are being even further eroded by the increasing complexity of clinical trials.

Finally, addressing the third count, the Hatch-Waxman Act makes matters worse and in effect further reduces expected pharmaceutical patent life by changing the calculus for generics that want to challenge a pharmaceutical patent as potentially invalid. In effect, the Hatch-Waxman Act actually makes pharmaceutical patents weaker than any other type of patent by making challenges to pharmaceutical patents easier and more attractive than for any other type of patent. To understand how this works, one needs to understand that, as with all types of patents, even the best pharmaceutical patent is not iron-clad. ${ }^{143}$ When pharmaceutical companies apply to the United States Patent and Trademark Office (PTO) for patent protection on their newly

\footnotetext{
137 ld.

138 Henry Grabowski, Are the Economics of Pharmaceutical Research and Development Changing? Productivity, Patents and Political Pressures, 22 PhaRMACOECONOMICS 15, 19 (2004); Grabowski \& Kyle supra note 105, at 492.

139 Kuhlik, supra note 17, at 96-97.

140 Congressional Budget Office, How InCreased Competition from Generic Drugs Has affected Prices and Returns in the Pharmaceutical Industry xiv (1998); Grabowski \& Vernon, Longer Patent Life, supra note 73, at 121.

141 Hughes et al., supra note 28 , at 5 (and sources cited therein).

142 Engelberg supra note 12, at 392.

143 See Blonder-Tongue Labs., Inc. v. Univ. of III. Found., 402 U.S. 313, 330-31, 331 n.21 (1971) (explaining the importance of litigating patent validity).
} 
developed drugs, the PTO does its best to assure that the drug meets all the various requirements for patentability. For all its efforts, however, the PTO often misjudges or outright misses evidence that a particular drug is not in fact eligible for patent protection. $^{144}$ Thus, under the Supreme Court's precedent in Blonder-Tongue, no pharmaceutical or other type of patent is ever declared definitively valid, for a court must constantly evaluate whether the patent before it is one that the PTO should not have granted. ${ }^{145}$ Given the uncertainty of the patentability requirements and the possibility that the PTO missed some relevant evidence of unpatentability, this means that many if not most patents are subject to at least colorable arguments that they are in fact invalid. Add to this the uncertainty of litigation and the vagaries of trial, and some of these colorable arguments may persuade a court that the patent at issue is invalid and should never have been granted in the first place. Moreover, under Blonder-Tongue, a patent is subject to such challenges throughout its lifetime, and if you subject the same patent to multiple challenges by multiple challengers, one of those challenges will likely succeed, if only by the weight of the odds. ${ }^{146}$

The Hatch-Waxman Act exacerbates this effect with regard to pharmaceutical patents by further reducing the costs of such opportunistic challenges and indeed rewarding them. For nonpharmaceutical patents, the probability of invalidation is a concern that is at least partially mitigated by the fact that patent litigation is a costly process, particularly for the losing party. ${ }^{147}$ This discourages many of the more spurious challenges and even some

\footnotetext{
144 As seen by the large number of patents that get invalidated through litigation.

145 Blonder-Tongue Labs, 402 U.S. at 330-31, $331 \mathrm{n} .21$.

146 For this very reason, patent rights have often been described as "contingent property right[s]," or "probabilistic property right[s]," Jay P. Kesan \& Marc Banik, Patents as Incomplete Contracts: Aligning Incentives for R\&D Investment with Incentives to Disclose Prior Art, 2 WASH. U. J.L. \& POL'Y 23, 25 (2000); Mark A. Lemley \& Carl Shapiro, Probabilistic Patents, 19 J. Econ. Perspectives 75, 76 (2005).

147 See, e.g., Jean Olson Lanjouw \& Mark A. Schankerman, Characteristics of Patent Litigation: A Window on Competition, 32 RAND J. ECON. 129, 132 (2000) (finding that because, inter alia, the probability of trial declines in the cost of trial relative to the cost of settlement, pharmaceutical patents are more likely to be litigated than other types of patents).
} 
of the legitimate ones. ${ }^{148}$ The Hatch-Waxman Act changes the calculus for generic manufacturers, however, in two significant ways.

First, as detailed above, the Act creates an artificial act of infringement when a challenger simply files a Paragraph IV certification with the FDA, asserting that the pharmaceutical patent at issue is invalid, not infringed, or both. ${ }^{149}$ Ordinarily, to create a justiciable case of infringement of non-pharmaceutical patents, an alleged infringer must invest in actually infringing a patent, thereby risking not only that investment but also liability for damages caused thereby. ${ }^{150}$ By contrast, generic challengers to pharmaceutical patents under the Hatch-Waxman Act risk neither, making such challenges almost risk-free, save for the cost of litigation. The result is a sort of Russian roulette for the brandname patent holder because generic challengers, one after the other, can continue to challenge the patent at almost no cost to themselves until one of them hits the jackpot and convinces a court to invalidate the patent. ${ }^{151}$

Second, successful generic first challengers also enjoy the prospect of 180 days of exclusivity profits, a bonus supposedly implemented on the notion that generic manufacturers would not invest their litigation dollars in invalidating a patent if other generic manufacturers would later be able to free-ride on that investment. ${ }^{152}$ The profits from 180 days of exclusivity can be quite substantial, however, and may likely more than compensate

148 See id.

149 See supra text accompanying notes 107-09.

150 Christopher M. Holman, Do Reverse Payment Settlements Violate the Antitrust Laws?, 23 SANTA ClaRA COMPUTER \& High TECH. L.J. 489, 523 (2007).

151 See id. at 524-25; see also C. Scott Hemphill, Paying for Delay: Pharmaceutical Patent Settlement as a Regulatory Design Problem, 81 N.Y.U. L. REV. 1553, 1606-07 (2006) (adverting to "probabilistic" nature of patent validity as inducement to file Paragraph IV challenges).

152 See Erika King Lietzan, A Brief History of 180-Day Exclusivity Under the HatchWaxman Amendments to the Federal Food, Drug, and Cosmetic Act, 59 FOOD \& DRUG L.J. 287, 288 (2004); CTR. FOR DRUG EVALUATION \& RESEARCH, Guidance for Industry: 180-Day Generic Drug Exclusivity Under the Hatch-Waxman Amendments to the Federal Food, Drug, and Cosmetic Act, FDA, at 3 (1998), www.fda.gov/downloads/Drugs/.../Guidances/ucm079342.pdf. 
for litigation costs. ${ }^{153}$ Indeed, in a duopolistic market, with just the brand-name innovator and the single generic challenger, both may be able to maintain a market price of as much as $94 \%$ of the original brand-name market price. ${ }^{154}$ This represents a loss for the brand-name innovator, who still has to recoup its sizable R\&D outlay, but a great windfall for the generic challenger, who has spent next to nothing in invalidating the patent. Moreover, given the low costs of challenging a patent and the high potential windfall from doing so, the more profitable the patented drug, the more likely a generic is to challenge the patent, even if the odds of succeeding in the challenge are low. ${ }^{155}$ The current trend is therefore for generic manufacturers to challenge an entire array of brand-name drug patents in hopes that they will win the jackpot on at least one of those challenges. ${ }^{156}$

The profits from the 180-day exclusivity decrease, of course, if more than one generic Paragraph IV filer is awarded the exclusivity, but even so remain quite high and, in any event, often well above their shared litigation costs. ${ }^{157}$ The lure of profits from the 180-day exclusivity period also remains quite substantial even if the brand-name innovator introduces its own lower-priced "authorized generic" version in order to gain a share of the generic market. ${ }^{158}$ It is thus clear that generic manufacturers who

\footnotetext{
153 Hemphill, supra note 151, at 1579-80.

154 Id. at 504-05.

155 Hemphill, supra note 151, at 1579-80.

156 Grabowski, supra note 138 , at 20.

157 See Grabowski \& Vernon, Longer Patent Life, supra note 73, at 116 (finding average generic price mark-ups to be $89 \%$, compared to average brand-name markups of $30 \%$, one year after generic entry); see also Hemphill \& Sampat, supra note 102, at 618 (referring to Paragraph IV litigation costs of approximately \$10 million); David Reiffen \& Michael R. Ward, Generic Drug Industry Dynamics, 87 Rev. ECON. STAT. 37, 44, 48 (2005) (noting that generic profits can remain well above competitive levels when only 2 to 4 competitors enter market).

158 See Ernst R. Berndt et al., Authorized Generic Drugs, Price Competition, and Consumers' Welfare, 26 Health AfFairs 790, 794 (2007) (noting that Paragraph IV filings do not decrease and may even increase as result of authorized generic introduction); FTC, Authorized Generics: An Interim Report of the Federal TradeCommission 85-92 (2009), available at http://www.ftc.gov/os/2011/08/20

11 genericdrugreport.pdf (noting that authorized generics have not deterred Paragraph IV challenges); see also John R. Thomas, Authorized Generic Pharmaceuticals: Effects on
} 
challenge pharmaceutical patents enjoy significant advantages that challengers to other types of patents never enjoy, making even relatively strong pharmaceutical patents more vulnerable to challenges than patents in any other industry or market. This is particularly true for flagship drug patents, which by virtue of earning the highest returns are also the most attractive targets for generic challenge. ${ }^{159}$ Attacking flagship drug patents particularly damages the brand-name pharmaceutical innovators, however, for those are exactly the drugs that subsidize not only their own development costs but also the costs of other beneficial but less profitable drugs. ${ }^{160}$ By weakening drug patents and lowering their overall expected value, then, the Hatch-Waxman Act lowers the expected returns on, and the incentives for investment in, the kind of pharmaceutical innovation that leads to such patents.

Indeed, Hatch-Waxman's effect on pharmaceutical patents has been measurable. At least one study suggests that Paragraph IV challenges by generic manufacturers shorten effective patent lives by at least 1.5 years, and that this holds true regardless of whether the challenges were successful. ${ }^{161}$ Of course, critics argue that the Paragraph IV certification provisions of the Hatch-Waxman Act benefit consumers by allowing generic manufacturers to weed out "bad" patents, by which they apparently mean patents that provide undue exclusivity. ${ }^{162}$ In particular, critics point to so-called "evergreening," or sequential, patents that brand-name manufacturers allegedly use to prolong their drugs' patent terms. ${ }^{163}$ Unlike active ingredient patents on an NCE itself-usually the first patent filed, before clinical testing even begins-sequential patents

\footnotetext{
Innovation, CRS Report for Congress, at 9 (August 8, 2006) (citing case where generic profits remained in hundreds of millions of dollars even after authorized generic entry).

159 See Hemphill, supra note 111, at 635; Thomas, supra note 158, at 18.

160 Krishan Maggon, $R \& D$ Paradigm Shift and Billion-Dollar Biologics, in HANDBOOK of Pharmaceutical Biotechnology 163 (Shayne C. Gad ed., 2007); Glover, supra note 42 , at 4 .

161 Grabowski \& Kyle, supra note 105, at 501.

162 E.g., Michael Kades, Whistling Past the Graveyard: The Problem with Per Se Legality Treatment of Pay-for-Delay Settlements, 5 COMPETITION POLICY INT'L 143, 147 (2009).

163 See, e.g., Hemphill \& Sampat, supra note 102, at 619. See generally Michael A. Carrier, A Real-World Analysis of Pharmaceutical Settlements: The Missing Dimension of Product Hopping, 62 FLA. L. REV. 1009 (2009).
} 
typically cover variations on delivering those active ingredients, such as different doses, different formulations, metabolites, or new uses of existing drugs. ${ }^{164}$ As such, sequential patents tend to be filed, and to expire, later than any patent on a drug's active ingredient. ${ }^{165}$ Critics therefore accuse brand-name pharma of using sequential patents to extend the nominal, although not necessarily effective, patent life on the underlying active ingredient. ${ }^{166}$

As it happens, sequential patents are also those that are most often challenged, and most often successfully challenged, under Hatch-Waxman's Paragraph IV provisions. ${ }^{167}$ Sequential patents rose starkly in number after Hatch-Waxman was enacted. ${ }^{168}$ Although many question these patents as merely strategic, they can also be seen as way of incentivizing investments in new indications and formulations, particularly after Hatch-Waxman opened the floodgates of generic market entrants. ${ }^{169}$-Sequential patents do tend to be "weaker," however, and are therefore more likely to draw Paragraph IV challenges. ${ }^{170}$ Active ingredient patents on the NCE itself are generally the strongest because they cover drugs never known before and therefore unlikely to have been anticipated by others. ${ }^{171}$ Active-ingredient patents are also the broadest in scope, excluding all others from making any reformulation of a drug containing that active ingredient. ${ }^{172}$ Sequential patents, by contrast, tend to be narrower in scope, covering only the particular reformulation claimed, and also weaker, in that the reformulations are more likely to be held invalid for anticipation or obviousness. ${ }^{173}$ Because generic

\footnotetext{
164 Eisenberg, supra note 57, at 354; Hemphill \& Sampat supra note 102, at 619-20, 623.

165 Id.

166 Hemphill \& Sampat, supra note 102, at 643 (noting that effective patent lives are often shorter than nominal patent lives).

167 Eisenberg, supra note 57, at 354; Hemphill \& Sampat, supra note 102, at 629,644

168 Hemphill \& Sampat, supra note 102, at 619-20.

169 Grabowski, supra note 138, at 20; Mossinghoff, supra note 71, at 191.

170 Hemphill \& Sampat, supra note 102, at 619.

171 Id. at 619-20, 623.

172 Grabowski \& Vernon, Longer Patents, supra note 73, at 119; Hemphill \& Sampat, supra note 102, at 619-20, 623 .

173 Hemphill \& Sampat, supra note 102, at 619-20, 623 .
} 
manufacturers can enjoy the 180-day exclusivity period regardless of which patent they challenge, they will often single out sequential patents for challenge even though they are limited to the particular reformulations claimed, if successful. ${ }^{174}$

If, however, sequential patents arose largely in response to Hatch-Waxman in an effort to fend off the increased generic market incursion under the Act, ${ }^{175}$ Hatch-Waxman's Paragraph IV certifications are being used largely just to challenge patents that would likely never have existed but-for Hatch-Waxman. Given the litigation costs of such challenges, the potential windfalls they create for generics, and the lower net revenue they create for brand-name pharma, this effective circularity would appear to be little more than an inefficient redistribution of wealth from brandname pharma to generic pharma. ${ }^{176}$

Another of the unintended consequences of the Paragraph IV provisions, moreover, has been a flood of allegations that brandname and generic pharmaceutical manufacturers are manipulating the legal system to achieve anti-competitive ends through so-called "reverse-payment settlements" of patent litigation. ${ }^{177}$ Given the high stakes and uncertainty of trial, patent holders - the brandname drug manufacturers - often settle with generic challengers by giving them cash, patent licenses, or other consideration, thereby "reversing" the expected flow of settlement payments. ${ }^{178}$ Because the direction of these transfers is admittedly unusual, it has prompted intense scrutiny. In particular, the Federal Trade Commission and others have argued that the only possible explanation for these unique settlements is that they thwart efforts to invalidate "bad" pharmaceutical patents and effectively pay

\footnotetext{
174 Id. at $622-23$.

175 Id. at $615-16$.

176 Cf. Schering-Plough Corp. v. FTC, 402 F.3d 1056, 1076 (11th Cir. 2005), cert. denied, 126 S. Ct. 2929 (2006) (citing In re Ciprofloxacin Hydrochloride Antitrust Litig., 261 F. Supp. 2d 188, 251 (E.D.N.Y. 2003) ("Hatch-Waxman essentially redistributes the relative risk assessments and explains the flow of settlement funds and their magnitude.").

177 See Holman, supra note 139, at 530-33.

178 Id. at 494 . ("The 'reverse' designation refers to the direction of the payment from the patentee to alleged infringer; in most patent litigation settlements, any payment will typically flow from the alleged infringer to the patentee.")
} 
generics to delay entry into the market for the patented drug. ${ }^{179}$ Under this logic, such settlements are inherently suspect or even per se illegal under Section One of the Sherman Act and harm the public by maintaining higher drug prices. ${ }^{180}$ Courts thus far have rejected complaints that these settlements are antitrust violations, holding instead that the agreements are within the "exclusionary zone" of patent protection and thus exempt from antitrust analysis. ${ }^{181}$ But just the fact that brand-name pharmaceutical patent holders have to deal with such an enhanced level of challenges to their patents and, indeed, have to deal with further challenges as to how they settled the original challenges, is yet another huge cost to the industry that creates even more uncertainty as to the value of investments in pharmaceutical R\&D.

\section{The Myth Of Generic COMPeTITION UndeR THe HatCH- WAXMAN ACT}

The ultimate irony of the Hatch-Waxman Act is that, in the end, the high cost of brand-name pharmaceutical innovations and the prices that consumers pay for that innovation really have nothing to do with either patent protection or even lack of competition within the pharmaceutical marketplace. The myth underlying the Hatch-Waxman Act is that the lower prices at which generic manufacturers can offer their drugs must mean that generic manufacturers are horizontal competitors to brand-name pharma. ${ }^{182}$ In other words, but for generic market entry, brand

\footnotetext{
179 Id. at $533-34$.

180 Id. Section One of the Sherman Act, which defines and prohibits anticompetitive conduct, provides that "[e]very contract, combination in the form of trust or otherwise, or conspiracy, in restraint of trade or commerce among the several States, or with foreign nations, is declared to be illegal ...." In re Cardizem CD Antitrust Litig., 332 F.3d 896, 906 (6th Cir. 2003) (citing 15 U.S.C. 11 (2004)).

181 On the debate regarding reverse payment settlements, see generally Hemphill, supra note 111; see also David W. Opderbeck, Rational Antitrust Policy and Reverse Payment Settlements in Hatch-Waxman Patent Litigation, 98 GEO. L.J. 1303, 1308-09 (2010); David Balto, Removing Obstacles to Generic Drug Competition, A Critical Priority for Health Care Reform, CTR. FOR AM. PROGRESS at 1 (2009), www.americanprogress.org/ issues/2009/06/pdf/generic_drugs.pdf.

182 See Liu, supra note 112, at 484; Elizabeth Stotland Weiswasser \& Scott D. Danzis, The Hatch-Waxman Act: History, Structure, and Legacy, 71 ANTITRUST L.J. 585, 590 (2003) (noting Congress' goal to increase generic competition).
} 
names would have no price-lowering competition, and therefore the Hatch-Waxman Act must introduce such competition by introducing greater generic presence within the pharmaceutical marketplace and by restraining the effect of patents on such competition. ${ }^{183}$ This myth is based on several different fallacies, including the idea that pharmaceuticals could ever be a competitive market, at least not without significant changes far beyond those contemplated by the Hatch-Waxman Act.

As an initial matter, it is important to appreciate that the pharmaceutical market is not a competitive one for a number of reasons beyond the regulatory burdens manufacturers might face, the presence or absence of generic manufacturers, and even the presence or absence of patent protection. ${ }^{184}$ True, the pharmaceutical market is burdened with stringent regulatory requirements and with relatively strong patent protection, both of which serve as obstacles to entry into this market, ${ }^{185}$ although not as much as one might think. First, as mentioned above, patents often pose little obstacle to competition, particularly from meaningful substitutes for the patented good or process. ${ }^{186}$ This is as true for pharmaceutical goods as it is for any other patented good; a drug often experiences significant competition from similar drugs or drugs that treat the same condition. ${ }^{187}$ Second, while regulatory requirements can discourage market entrants, they are hardly an absolute barrier unless specifically designed to be so, like those under the Hatch-Waxman Act. Before the Act was put in place, the FDA did not actively keep others from entering a market to compete with a drug already approved for marketing; all a would-be competitor would have to do is meet the regulatory requirements itself and thereby secure its own FDA approval to

\footnotetext{
183 See Weiswasser \& Danzis, supra note 184, at 590 (discussing historical background and purpose of the Hatch-Waxman Act).

184 See Sloan \& Hsieh, supra note 21, at 5.

185 See Eisenberg, supra note 65, at 121.

186 See Sloan \& Hsieh, supra note 21, at 9.

187 Timothy J. Muris, Chairman, FTC, Address Before the 7th Annual Competition in Health Care Forum: Everything Old Is New Again: Health Care and Competition in the 21 st Century (Nov. 7, 2002), in 2002 WL 31504162, at 6 n.47; see Glover, supra note 42, at 6-7.
} 
market a competing drug. ${ }^{188}$ This is exactly what many competitors did before the Act and what they continue to do even after the Act. Indeed, even now that the Act is in place, competitors who have themselves obtained FDA approval may enter a market to compete with an approved drug, as long as the competitors' drugs are not identical or near identical copies of an approved drug that enjoys NCE or other types of marketing exclusivity.

Nevertheless, even if the pharmaceutical industry possessed no patents and faced no regulatory requirements, the market for pharmaceuticals would still not be a competitive one. For one thing, private insurers and other third-party payors not only interrupt the chain between patient consumers and pharmaceutical manufacturers but also skew the demand for those pharmaceuticals. ${ }^{190}$ The entire third-party payor system means that consumption of pharmaceuticals does not always reflect their social benefit, particularly where the consumer does not bear costs in proportion with the overall cost of the drugs consumed. ${ }^{191} \mathrm{~A}$ 2000 report revealed that $69.3 \%$ of all prescription drug costs were paid not through patient consumers but through third-party payors, with $13 \%$ of that paid by state-run Medicaid programs. ${ }^{192}$ Insured patients and patients covered by government programs therefore are more often than not completely unaware of the true price of their prescriptions, such that their demand rarely reflects either supply or price. ${ }^{193}$ Indeed, for a number of reasons, consumer

\footnotetext{
188 See Liu, supra note 112, at 455-56.

189 See Kuhlik, supra note 17, at 103-04.

190 See Sloan \& Hsieh, supra note 21, at 3.

191 See id.

192 See Grabowski, supra note 26, at 156.

193 See Sarah Fisher Ellison, et al., Characteristics of Demand for Pharmaceutical Products: An Examination of Four Cephalosporins, 28 RAND J. ECON. 426, 427 (1997) (noting that physicians, from whom consumers get their information, have limited knowledge regarding relative drug prices); Matthew J. Seamon, Antitrust and the Biopharmaceutical Industry: Lessons from Hatch-Waxman and an Early Evaluation of the Biologics Price Competition and Innovation Act of 2009, 34 Nova L. REv. 629, 63840 (2010) (explaining the inelastic nature of pharmaceutical drugs). But see OlIVER Gassmann et al., Leading Pharmaceutical innovation Trends and Drivers for GROWTH IN THE PHARMACEUTICAL INDUSTRY 25 (2d ed. 2008) (noting that consumers are starting to become more aware of drug prices).
} 
demand for pharmaceuticals is relatively inelastic. Patients lack the kind of information necessary to make consumption decisions based on price, quality, or other values, for these decisions are typically made for them by their physicians, hospitals, and insurers. ${ }^{194}$ Moreover, as the ultimate payors for pharmaceuticals, both the government and private insurers can often exert great bargaining power in negotiating price with brand-name as well as generic pharmaceutical manufacturers, again skewing pharmaceutical prices away from what they might have been in a freely competitive market. ${ }^{195}$

It is therefore a good thing that the pharmaceutical industry is as heavily regulated as it is and that it can rely on patent protection as much as it does-otherwise, the industry might not have survived, and undoubtedly would not operate to the optimal level of benefit to society. ${ }^{196}$ In fact, for years the government has effectively subsidized various aspects of the pharmaceutical industry through federal tax deductions and credits for R\&D expenditures, ${ }^{197}$ federal grants supporting upstream research, and regulatory exclusivities such as the Orphan Drug Act. ${ }^{198}$ Indeed, society would not necessarily want the pharmaceutical industry, or any other health care industry, to act too much like a freely competitive market, for that might lead to tragic choices in terms of who receives such benefits and who does not. ${ }^{199}$

Given the largely non-competitive nature of the pharmaceutical and health care markets more generally, it is somewhat puzzling that the Hatch-Waxman Act should focus so entirely on generic

\footnotetext{
194 See Caves, supra note 59, at 5-6; Sloan \& Hsieh, supra note 21, at 3, 5.

195 See GASSMANN ET AL., supra note 193, at 25-26 (commenting on bargaining power of HMOs and even government entities).

196 See Uwe E. Reinhardt, The Pharmaceutical Sector in Health Care, in PhaRmaCEutical INNOVATION: INCENTIVES, COMPETITION, AND COST-BENEFIT ANALYSIS in International Perspective 25, 29-30 (Frank A. Sloan \& Chee-Ruey Hsieh eds., 2007); Weiswasser \& Danzis, supra note 151, at 586.

197 See Kevin Outterson, Pharmaceutical Arbitrage: Balancing Access and Innovation in International Prescription Drug Markets, 5 YAle J. HeAlTH POL'Y. L. \& ETHICs 193, 221 (2005). See generally Crimm, supra note 32; DiMasi et al., supra note 53.

198 See Daniel J. Gervais, Intellectual Property, Trade \& Development: The State of Play, 74 FordHAM L. REV. 505, 523 n.97 (2005).

199 See, e.g., M. Gregg Bloche, The Invention of Health Law, 91 CAL. L. REV. 247, 318 19 (2003).
} 
market entry and removing barriers to that entry as a way of creating a more competitive marketplace. True, generic manufacturers can offer pharmaceuticals at lower prices than brand-name manufacturers and often are prevented from doing so by patent protection of various brand-name drugs. ${ }^{200}$ But this is a far cry from saying that patents and other barriers to generic market entry are what truly cause the differential in brand-name and generic pricing-i.e., but for the lack of competition between these two sectors of the pharmaceutical industry, consumers would enjoy lower drug prices. Rather, closer examination reveals a whole raft of other reasons why generics can price so much lower than brand-names, and all those reasons have to do with the fact that generic manufacturers, by their nature, free-ride on brandname manufacturers' investments in pharmaceutical innovation.

First, the Hatch-Waxman Act assumes that brand-name pharmaceuticals charge supra-competitive prices because, and only because, they lack competition within the marketplace, either by virtue of patent protection or by virtue of the simple absence of generic competition. $^{201}$ Economists have shown, however, that brand-name pharmaceutical pricing, even without patent protection, is not based on competition from generics, but rather on competition from alternatives within the same therapeutic class, ${ }^{202}$ not to mention the need to recoup R\&D and other costs. ${ }^{203}$ Indeed, even after generic entry, brand-name pharmaceuticals do not lower their costs to those of the generic, but rather maintain relatively higher prices despite the loss in sales. ${ }^{204}$

Second, the myth of generic competition underlying the HatchWaxman Act relies on the fallacy that generics can provide meaningful competition for brand-name pharmaceuticals in anything other than price. ${ }^{205}$ To appreciate the fallacy of this reasoning, one need only look at the patent system and its

\footnotetext{
200 See Melissa K. Davis, Note and Comment, Monopolistic Tendencies of Brand-Name Drug Companies in the Pharmaceutical Industry, 15 J.L. \& CoM. 357, 357 (1995).

201 See Liu, supra note 112, at 443.

202 See id. at 480; Sloan \& Hsieh, supra note 21, at 9.

203 See Sloan \& Hsieh, supra note 21, at 9; see also Liu, supra note 112, at 488.

204 Saha et al., supra note 25 , at 28.

205 See Liu, supra note 112 , at $484-85$.
} 
underlying policies. Patents are commonly conceived of as "embarrassments" to antitrust law in that they insulate the patentee from free market competition. ${ }^{206}$ This is true, but only to the extent that they protect patentees from competition as to price, for patents are designed to do far more than protect against mere price competition. Rather, patents are designed to incentivize innovation by protecting investments in innovation from those who would seek not to compete with the innovation, but rather simply to freeride on it. ${ }^{207}$ Patents thus protect innovation, which is not something generic manufacturers provide, just as they do not provide education, safety and efficacy data, or many other social benefits that brand-name pharmaceuticals provide. ${ }^{208}$

Indeed, the fact that generic pharmaceutical manufacturers provide so little other than mere manufacturing and distribution is exactly what separates them from brand-name manufacturers, and what leads to the steep differential in their respective market pricing. Consider first each sector's respective R\&D investments. $\mathrm{R} \& \mathrm{D}$ is a valuable output, without which no new drugs would be identified. Brand-name innovators invest in and produce a great deal of $R \& D$, but generics obviously produce none. ${ }^{209}$ The same can be said of clinical trials data on the safety and efficacy of new drugs. If it were not for the fact that brand-name innovators invest the millions of dollars necessary to produce safety and efficacy studies, the burden would be shifted onto patients and health care providers, who would then have to make their own investments in determining which drugs on the market are safe and effective and which are not. Generic manufacturers used to have to produce this service as a pre-requisite to FDA marketing approval, but the Hatch-Waxman Act quite sensibly recognized this investment as duplicative and wasteful, given that generics produce no new drugs

206 See T. Randolph Beard, et. al., Quantifying the Cost of Substandard Patents: Some Preliminary Evidence, 12 YALE J.L. \& TECH. 240, 243-244 (2010).

207 See U.S. CONST. art. I, $\& 8$, cl. 8. ("Congress shall have the power . . . to promote the Progress of Science and useful Arts, by securing for limited Times to Authors and Inventors the exclusive Right to their respective Writings and Discoveries."). See also Sloan \& Hsieh, supra note 21 , at 9.

208 See Liu, supra note 112, at 484-85.

209 See id. 
that brand-name innovators have not already tested. ${ }^{210}$ Generics therefore may now free-ride not only on the brand-name innovators' R\&D investments, but also on their safety and efficacy studies. $^{211}$

Similarly, generics can free-ride on brand-name innovators' investments in so-called "detailing," which are the large marketing and education outlays that the innovators generally must invest in whenever they market a new drug. ${ }^{212}$ Brand-name innovators typically concentrate these investments within the first two years after market launch of the new drug, although they will often continue up to generic market entry. ${ }^{213}$ Generic manufacturers, by contrast, typically invest nothing in product-specific detailing, relying instead on overall firm marketing. ${ }^{214}$ And although critics of brand-name pharma, as well as the public, are generally skeptical of such expenditures as nothing but naked rent-seeking, detailing actually does provide a significant social benefit in terms of introducing new drugs to those who need to understand them, such as physicians, hospitals, and even patients. ${ }^{215}$ Again, although these detailing investments obviously serve the self interests of brand-name manufacturers, these outlays in distributing information also save consumers and health-care providers from having to make as great an investment on their own in identifying and understanding which new drugs are on the market. ${ }^{216}$ Indeed,

210 See Douglas A. Robinson, Note, Recent Administrative Reforms of the HatchWaxman Act: Lower Prices Now In Exchange for Less Pharmaceutical Innovation Later?, 81 WASH. U. L.Q. 829, 834-35 (2003).

211 See id. Generic manufacturers do have to provide data that their generic equivalents have the same active ingredient, route of administration, dosage form, strength, and labeling as the brand-name drugs that they imitate. Id.

212 Pharmaceutical Detailing, SEARCHHEALTHIT, http://searchhealthit.techtarget.com/ definition/detailing (last updated Feb. 2011).

213 See Comanor, supra note 71, at 59.

214 Branstetter et al., supra note 123, at 17; Scott Stern, Market Definition and the Returns to Innovation: Substitution Patterns in Pharmaceutical Markets (Nat'l Bureau of Econ. Research, Working Paper No. 17188, 1996), available at http://www.nber.org/ papers/w17188.

215 Caves et al., supra note 59, at 11-12; Sloan \& Hsieh, supra note 21, at 6; Susan Heilbronner Fisher, Note, The Economic Wisdom Of Regulating Pharmaceutical "Freebies", 1991 DUKE L.J. 206, 225-28 (1991).

216 Fisher, supra note 215 , at 226-27. See also PHARMACEUTICAL RESEARCH AND Manufacturers of America, The facts About Pharmaceutical Marketing and 
manufacturer-provided detailing may be a much more effective and cost-efficient way than physician research in providing important information to both health-care providers and consumers. ${ }^{217}$

Last, but not least, generic manufacturers do not face the same risks that brand-name innovators do. For one thing, generic manufacturers are much more able to hedge against the risk of negative profit margins, for they quite consciously choose to imitate only those brand-name drugs that are profitable. ${ }^{218}$ Brandname manufacturers, on the other hand, may not necessarily know ex ante which drugs will be profitable at the very early point in time of deciding whether to invest in the R\&D to develop such a drug. The majority of drugs turn out to be economically unprofitable, even if socially quite beneficial, and so brand-name innovators are forced to rely on their few flagship drugs to subsidize the rest. ${ }^{219}$ Again, only $30 \%$ of marketed drugs earn enough profit to cover their own development costs, and even fewer earn enough to cover the costs of other, less profitable drugs. $^{220}$ Generic manufacturers therefore can generate much more pure profit from those drugs that they do decide to market.

For another thing, generic manufacturers may face less risk than brand-name manufacturers in terms of product liability and may even be able to shift some of that liability onto brand-names. Courts have repeatedly held that generic manufacturers are effectively exempt from failure-to-warn liability suits under federal law. ${ }^{221}$ Under federal law, manufacturers must generally mark generic versions of a drug with labels that are identical to the FDAapproved labels attached to the brand-name version. ${ }^{222}$ They are

PROMOTION 12 (2008) (citing research that consumers find manufacturer promotional materials educational).

217 Id. at 226.

218 See Grabowski, supra note 26, at 160.

219 See GASSMANN ET AL., supra note 42, at 1, 4, 52 (2d ed. 2008); Glover, supra note 42 , at 4 .

220 Fasel, supra note 76, at 123-24.

221 See generally Parasidis, supra note 53; Allen Rostron, Prescription for Fairness: A New Approach to Tort Liability of Brand-Name and Generic Drug Manufacturers, 60 DUKE L.J. 1123 (2011).

222 Rostron, supra note 221, at 1135-38. 
therefore often exempt from liability for failure to warn under federal law. ${ }^{223}$ A recent Supreme Court case has effectively extended this exemption by holding that federal law preempts any state law claims of liability as well. ${ }^{224}$ By contrast, the California Court of Appeals recently ruled that, because a generic label must be identical to the brand-name label, a brand-name drug manufacturer may be liable for a generic manufacturer's failure to warn. $^{225}$

Moreover, although brand-name innovators rely heavily on patent protection to fend off generic imitators and other free-riders, patents are actually rather poor tools for the job. The patentability of new drugs depends solely on their ability to meet requirements such as novelty, non-obviousness, and utility ${ }^{226}$ but has little to do with their development costs, profitability and, perhaps most notably, their social value. ${ }^{227}$ Innovators hope that patents will nonetheless help them recoup their costs and generate a little profit, but the patent system can offer no guarantees. Instead, the patent system relies on the market to incentivize and reward investments in innovation, but as discussed above, the market is an unreliable means of incentivizing pharmaceutical innovation and other health care goods and services. ${ }^{228}$ Indeed, some propose that industry regulators simply acknowledge this fact and offer to strengthen the pharmaceutical patent of a manufacturer's choice if it produces low-profit drugs and vaccines. ${ }^{229}$ Yet others suggest

\footnotetext{
223 Id.; Parasidis, supra note 53, at 957-58.

224 Parasidis, supra note 53, at 957-58 (discussing PLIVA, Inc. v. Mensing, 131 S. Ct. $2567(2011))$.

225 See generally Rostron, supra note 221 (discussing Conte v. Wyeth, Inc., 85 CAL. RPTR. 3d 299 (Ct. App. 2008)).

22635 U.S.C. $\$ 101$ (2006) (defining patentable subject matter as "any new and useful process, machine, manufacture, or composition of matter, or any new and useful improvement thereof'); 35 U.S.C. $\S \S 102,103$ (2006) (requiring that inventions be novel and nonobvious).

227 See, e.g., Maxwell R. Morgan, Regulation of Innovation Under Follow-On Biologics Legislation: FDA Exclusivity as an Efficient Incentive Mechanism, 11 CoLUM. SCI. \& TECH. L. REV. 93, 105 (2010) ("Yet the relationship between the patentability of a therapeutic candidate and its potential social value if advanced through clinical testing is tenuous at best.")

228 Supra note 153 and accompanying text; Sloan \& Hsieh, supra note 21, at 2.

229 See Aidan Hollis, Drugs for Neglected Diseases: New Incentives for Innovation, in Pharmaceutical InNOVATION: InCENTIVES, COMPETITION, AND Cost-Benefit ANALysis
} 
that longer regulatory exclusivities might be better suited to assuring some reasonable return on pharmaceutical innovation. ${ }^{230}$ The Hatch-Waxman Act and other statutory provisions do offer pharmaceutical innovators such exclusivities, but one has to wonder whether they are currently adequate to protect incentives to invest in such innovation. ${ }^{231}$

In sum, it is difficult to conceive of generic manufacturers as representing competition for brand-name pharmaceutical manufacturers in any real sense. Generics do not increase efficiency or offer greater consumer choice but rather market at lower prices simply because they copy from and free-ride on brand-name manufacturers. Given this reality, one has to question whether the Hatch-Waxman Act's focus on generics as supposed competition is a mistake. Indeed, one must question whether any effort to inject competition into the pharmaceutical market is truly the most effective way of reducing consumer costs. In balancing static efficiency (lower costs now) with dynamic efficiency (continued innovation and perhaps lower costs later), the law must be careful to foster only as much competition as is consistent with overarching regulatory goals. ${ }^{232}$ Over-privileging the value of competition in the pharmaceutical market may ultimately discourage continued innovation by brand-name pharmaceuticals.

\section{CONCLUSION}

Without a doubt, health care costs are on the rise, and how to reduce those costs is of great concern to many. ${ }^{233}$ In response to these concerns, the Hatch-Waxman Act sought to reduce one aspect of health care costs, the price of pharmaceuticals, by encouraging generic pharmaceutical manufacturers to enter the market as price competition to brand-name pharmaceutical

\footnotetext{
In International Perspective 75, 87-89 (Frank A. Sloan \& Chee-Ruey Hsieh eds., 2007) (commenting on such proposals).

230 See generally Goldman et al, supra note 15.

231 See Grabowski, supra note 26, at 171.

232 See Sloan \& Hsieh, supra note 21, at 11.

233 Ezekiel Emanuel, How Much Does Health Cost?, N.Y. TimEs, Oct. 30, 2011, at SR5, available at http://query.nytimes.com/gst/fullpage.html?res=9E06E7D9143DF933 A05753C1 A9679D8B 63\&scp=1 \&sq=how + much + does + health+cost \&st=nyt.
} 
manufacturers. ${ }^{234}$ The Hatch-Waxman Act has undoubtedly contributed to the much greater generic entry now seen in the pharmaceutical market, but the Act seems to have neglected some important considerations. Brand-name manufacturers set higher prices for their pharmaceutical goods for a reason. Brand-name pharma is the industry sector that invests hundreds of millions of dollars annually in not only researching and identifying new drug candidates but also in exhaustively testing those candidates for safety and efficacy before releasing them to the public. ${ }^{235}$ Generic manufacturers, on the other hand, produce none of these and other incredibly important but incredibly expensive outputs and therefore can market drugs at mere production cost. ${ }^{236}$

Indeed, for a variety of reasons, the Hatch-Waxman Act appears to misprize the value and even possibility of "competition" within the pharmaceutical market. As a result, the ultimate effect of the Act seems to be a sacrifice of long-term efficiency and continued pharmaceutical innovation for the sake of short-term price reductions. Hatch-Waxman seems grossly to have overshot the mark in terms of lowering pharmaceutical prices and encouraging generic entry. Perhaps simply streamlining FDA approval for generics, providing generics with an experiment-use exemption, or both, would have been more than enough to facilitate generic market entry without unduly sacrificing brandname pharma's incentives to continue innovating. This may be particularly true now that state laws and private insurers have both changed their policies to favor, rather than discriminate against, generics. Whether the Hatch-Waxman Act is a sustainable model for the pharmaceutical industry more generally has yet to be seen, but the signs so far are not promising. We may therefore want to reconsider the Hatch-Waxman Act in favor of other, more balanced approaches to lowering pharmaceutical consumer costs that would do more to protect incentives for innovation in the industry.

234 Engelberg, supra note 12, at 389.

235 Sloan \& Hsieh, supra note 21, at 4.

236 See Fiona M. Scott Morton, Entry Decisions in the Generic Pharmaceutical Industry, 30 RAND J. ECON. 421, 422 (1999). 